\title{
Hücresel Özişlem Yöntemi ile İzmir Körfez Tüp Geçiş Projesinin Rant Artışına Etkisinin Tahminlemesi: İnciraltı Örneği
}

\author{
Forecasting the Effects of Izmir Bay Tube-Tunnel Project on Rent \\ Increase with Cellular Automata Method: The Case of Inciraltı
}

\author{
Hüseyin Mert Arslan, ${ }^{1}$ (D) Yavuz Duvarcı \\ ${ }^{1}$ İzmir Bakırçay Üniversitesi, Fen-Edebiyat Fakültesi, Coğrafya Bölümü, İzmir \\ ${ }^{2}$ İzmir Yüksek Teknoloji Enstitüsü, Mimarlık Fakültesi, Şehir ve Bölge Planlama Bölümü, İzmir
}

\section{ÖZ}

Bir kentin zaman içerisinde uğradığı değişimin, gelişme yönünün ve arazi kullanımlarındaki değişim eğilimlerinin simülasyonlarla belirlenmesi ile geleceğe yönelik tahminler yapmak etkili bir planlama çalışmasında oldukça önemlidir. Mevcut literatürde, kentlerin çevreye yayılımı; Hücresel Özişlem, Çok Ajanlı Sistemler, Yapay Sinir Ağları gibi karmaşı sistem modelleme teknikleri ile modellenmektedir. Hücresel Ozişlem bu yöntemlerin en çok uygulananlarından biridir. Kentsel mekanın zamanda uğradığı değişim ve CBS'de Hücresel Özişlem (HÖ) yöntemiyle tahminlenmesi önemi artan bir konu olmuştur. Ülkemiz gündeminde yer alan köprü, tüp geçit, vb. projelerin kendileri kadar önemli ekonomik, sosyal ve çevresel etkileri vardır. Özellikle bu tür mega-projelerin kentsel rantlara olduğu kadar, planlama süreçlerine de olumlu/ olumsuz ikincil ve sinerjik etkileri bulunmaktadır. Bu tür etkilerin gelecekte ne olacağı da planlama açısından aynı derecede önemlidir. Ancak, mega-projelerin kentsel ranta söz konusu yöntemle etkisinin ele alınması oldukça yenidir. Rayiç bedel ve rantı belirleyen parametreler hakkında emlakçı görüşleri veri alınarak İzmir İnciraltı'ndan geçmesi planlanan İzmir Körfez Tüp Geçiş Projesinin (IKTG) HO ile üç olası senaryo bazında ve 2016'dan sonra beşer yıllık dönemlerde rant etkileri simüle edilmiştir. Yöntemin işleyiş sınaması yapılmış, İnciraltı bölgesindeki rantların geleceğe ilişkin verisi üretilmiştir. IKTG'nin, bölgenin hangi noktalarına güçlü etkide bulunabileceği gözlemlenmiştir. Böylece, büyük projelerin olası rant etkisi ile ilgili planlamanın yararlanabileceği ve ileride yazılıma dönüştürülebilecek elverişli bir araç geliştirilmiştir.

Anahtar sözcükler: Hücresel özişlem; İzmir Körfez Tüp Geçiş Projesi; kentsel rant.

\begin{abstract}
Using simulations and perform predictions with results of the simulation to discover the changes in cities over time, the direction of growth and tendency of change patterns is pretty vital for an effective planning study. In the current literature, the sprawl of cities to their closer environs have in general been modeled by complex methods such as Cellular Automata, Multi-agent Systems and Artificial Neural Networks. Cellular Automata is one of the most common of these methods. Urban spatial change and its simulation by GIS-based Cellular Automata (GCA) is a trending issue. Such mega-projects as the bridge and tube-tunnel projects, etc., which are at the agenda of our country, are supposed to have quite important socio-economic and environmental impacts as well as the importance given to the traffic relief and transportation. These big project are known to have the secondary and synergetic impacts on urban rental values, too, and also positive and negative effects on the planning process. However, estimation of urban rent impacts of mega-projects through the method is quite new. Using data of current land values and realtor opinions on determining rent parameters, rent impacts were estimated for Izmir Bay Tube-Tunnel Project (IBTT) for three scenarios and 5-year periods after 2016. The method utility was tested for Inciraltı region, and which locations would be significantly affected by the IBTT were detected. A useful instrument that the planning can use to know rent impacts of big projects, which can be a software application in the future, was developed. Keywords: Cellular automata; İzmir Bay Tube-Tunnel Project, urban rent.
\end{abstract}




\section{Giriş}

Zaman-mekan kavramları ile ilgili çalışmalarda Coğrafı Bilgi Sistemleri (CBS) tabanlı simülasyon modelleri ve son yıllarda Hücresel Özişlem - HÖ (Cellular Automata - CA) ile entegrasyonu kentsel büyüme (mekansal yayılma) simülasyonu çalışmalarında dikkat çekmektedir (Liu vd., 2005). Kentse alanlarda arazi kullanım tahmini çalışmalarında amaç, kentse gelişimin doğrudan saptanması yerine, kent planlama sürecinin sentez aşamasında alan kullanımı ve gelişme meyillerinin saptanmasına fayda sağlayacak veriler elde etmektir (Yüzer ve Yüzer, 2006). Türkiye ve dünyada ilgili literatür incelendiğinde, kentsel büyüme ve arazi kullanımının değişimi ile ilgili çalışmalarda Hücresel Özişlem (HÖ), Markov Zinciri, Yapay Sinir Ağları, SLEUTH Modeli vb. birçok simülasyon modeli geliştirilmiş ve uygulanmıştır (Turner, 1987; Meaille ve Wald, 1990; Landis, 1995; Clark vd., 1997; Clark ve Gaydos, 1998; Li ve Yeh, 1998; Sui ve Zeng, 200I; Torrens ve O’Sullivan, 200I). İleride belirlenen bir yıl için arazi kullanım senaryolarının üretilmesi; gerçekleşebilecek değişim miktarı ve yerlerinin tespitine, bu nedenle olası değişimlerin araştırılması ve planlama çalışmalarında gerekli önlemlerin alınmasına yarar sağlamaktadır. Bu anlamda, modellemenin doğruluğu kullanılacak verinin çözünürlüğü ve yöntemi ile önemli derecede ilişkilidir.

Simülasyon modelleri, çalışmaların doğruluk derecelerini artırması bakımından CBS ile birlikte gerçeğe yakın analizler yaparak, arazi kullanımı ile ilgili tahminler yapmaktadır. Başta kıyı bölgeleri olmak üzere, benzer gelişme baskısı altında kalan alanlarda, kentsel kullanımların değişim eğilimlerini belirleyerek tahminlerin yapılması ve planlamayı yönlendirmesi bakımından önemlidir. Ne var ki, literatürde HÖ yöntemi ile büyük ulaşım projelerinin etkileri konusunda, özellikle kentsel rant bazındaki etkilerin ölçülebileceği bir modelleme çaIışmasına rastlanmamıştır. Önemli ulaşım projelerinin hayata geçirildiği yakın dönemde söz konusu nitelikteki projeler ile kentsel rant arasındaki ilişkilerin, özellikle emlak değeri ve kentsel arazi yapısı arasındaki yakın etkileşim nedeniyle ortaya konulması önem arz etmektedir. Çünkü bu ilişkilerin doğru ve güvenilir olarak tespiti hem kentin gelişimini yönlendirmesi açısından hem de projelerin finansmanında alternatif modellerin uygulanması açısından önemlidir.

Bu çalışma temelde büyük ulaşım proje ve yatırımlarının kentsel rantlara olan etkileri ve bu etkilerden kaynaklı dolaylı çevresel etki, kır-kent dengesi ve arazi kullanımı farklılaşmalarına olan etkileri ile ilgilidir. Etkiler, mekansal bazda bir CBS tabanlı HÖ modeli çerçevesinde incelenmiştir. Araştırma, halihazırda İzmir kenti için önerilen önemli bir ulaşım projesi (tüp geçiş projesi ve çevre yolları bağlantıları) bağlamında konuyu ele almış ve projenin yakın çevresine etkileri ile sınırlı kalınmıştır. Belirlenen parametreler bazında değerlendirmeler yapılmıştır. Mekansal kapsam olarak çalışma alanımız İzmir-İnciraltı bölgesinden geçirilmesi planlanan İzmir Körfez Tüp Geçiş Köprüsü'nün, bölgede gerçekleşecek bağlantı yolları çevresinde oluşabilecek rant artışlarına yol açıp açmayacağı ve bu tür büyük yatırım kararlarının gayrimenkul değerlerini ne oranda etkileyeceği ilgili bölge ile sınırlı olacaktır. Ayrıca, bu tür ulaşım projelerinin rantsal etkilerinin belirlenen yöntem ve parametreler üzerinden nasıl gerçekleşebileceği konusunda bir yöntem denemesi amaçlanmıştır.

Çalışmanın temel hedefi, CBS tabanlı HÖ yöntemi kullanarak önemli ulaşım proje ve yatırımlarının etki alanına giren arazi kullanımlarındaki değişiklikleri inceleyerek farklı planlama yaklaşımlarıyla buradaki kentsel rantların değişimini tespit etmek ve bunlara uygun geleceğe yönelik bir simülasyon sistemi (veya şeması) geliştirmektir. Bu çalışma sonucunda, CBS tabanlı HÖ yöntemi gelecekteki değişimin tahminlenmesinde ve alan kullanım değişiminin yönü, miktarı ve mekansal dağılımının kent analizlerinde faydalı bir biçimde uygulanabileceği düşünülmektedir. Bunların yanında kullanılacak verilerin toplanması, düzenlenmesi, işlenmesi ve sonuçların çıktısı için bilgisayar ve yazılım destekli bir aşamanın gerçekleşmesi gerekir. Bu da çalışmamızın ikinci ayağını oluşturacak CBS tabanlı HÖ yönteminin işletilmesiyle mümkün olacaktır. Bu yüzden bu model ve yöntem hakkında ilgili literatür incelenmiştir.

\section{İlgili Literatüre Genel Bir Bakış}

Kent planlaması, rantın oluşmasında etkili olan bir girdidir ve rantın kentsel alanlarda uygulandığı biçimiyle genel olarak iki düzeydedir; Birincisi, kentsel kullanımların yerleşme ilkelerini ve gelişmelerin niteliğini kesin olarak belirtmeksizin, toprağın kullanım biçimini, başlıca kullanım bölgeleri ve ulaşım sistemi temelinde belirleyen ve gelişmenin ana çizgilerini gösteren nazım imar planıdır. İkincisi, belirli bir gelişim için, süreç başlamadan önce geliştiricinin yerel planlama otoritesinden almak zorunda olduğu planlama iznidir. Gelişmenin ana çizgilerini belirleyen nazım planın aksine, gelişim sürecine ilişkin planlama izni durum temelinde değerlendirilir. Bununla birlikte verilecek kararın nazım plana uygun olması gerekir (Keleş, 2004; Harvey, 1996).

Zaman içinde kent nüfusunun artması, artan nüfusun ihtiyaçlarının farklılaşması ve üretim ve bölüşüm ilişkilerinin değişmesi de kentin büyümesine ve dolayısıyla toprak kullanımında ve değerlerinde değişime yol açar. Bu da kent alanlarında gelecekteki büyüme ve gelişme yönüne göre belli miktarlarda yeni alan ihtiyacı yaratır. Koşulların değişmesi sonucu başlayan gelişim süreci ya da imar faaliyetleri farklı biçimlerde kendini gösterebilir. Bu süreçte, planlama sistemi büyük ölçüde emlak piyasasının baskıları ve talepleri doğrultusunda örgütlenir ve yapılanır. Yerel planlar oluşturularak ve imar denetim gücünü kullanarak toprak arzını sınırlayan yerel yönetimlerin bu uygulamaları sonucunda toprak değerleri yükselebilir. Toprak 
değerleri üzerindeki bu etkisinden dolayı planlamanın, bir bütün olarak toplumdan çok, emlak geliştiricilere ve yatırımcılara fayda sağladığı ileri sürülmektedir (Balchin ve Bull, 1987). $\mathrm{Bu}$ durum planlama sisteminin toprak spekülasyonuyla çok yakın ilişki içinde olduğunun kanıtı olarak değerlendirilmekte ve planlama sisteminin gelir ve refah bölüşümündeki eşitsizlik ile kaynak kullanımındaki etkinsizliği artırdığı ileri sürülmektedir. Bu tespit, toprak sahiplerinin, geliştiricilerin ya da spekülatörlerin planlamaya ilişkin gerekli izinleri alabilmek ve süreci kendi çıkarları doğrultusunda yönlendirebilmek için merkezi ya da yerel yönetim düzeyindeki girişimlerine açıklık getirmektedir (Evans, 1991).

Kentte bulunan ticaret ve yoğun konut alanları rantın yoğunlaştığı alanlardır. İş alanları, alışveriş merkezleri, manzarası, havası, mimarisi daha kaliteli olan üst gelir gruplarının tercih ettiği konut alanları tartışmasız kentsel rantın en yüksek olduğu alanlardır. Kent merkezine doğru yaklaştıkça kentsel toprakların da değeri artmaktadır (Keleş, 2004). Ancak ulaşım maaliyetlerine yönelik yatırım ve gelişmeler beraberinde kentin çevresinde arsa spekülasyonuna neden olmaktadır. Yatırım ve gelişmelerin fazla olduğu sınırlı alanda, alan büyüyemediği için yüksek rant değerlerinin görülmesi kaçınılmazdır. Büyümenin hızlı görüldüğü yerlerde sürdürülebilir planlamanın sağlanması için kentsel büyümenin kontrol altına alınması gerekir (Kalabalık, 20I I). Dahası, mevcut büyümenin izlenmesi ve ne yönde gelişeceğinin ön görülmesinde simülasyon modellerinin kullanılması önemlidir. Simülasyon modellerinin sonuçları ile kentsel rantın kent bütününe olan gelecekteki etkilerinin ne olacağını daha önceden farkına varmamızı sağlayarak gerekli politikaların üretimine olanak sağlamaktadır.

Günümüzde kent ile ilgili modellemeler genellikle mekansal simülasyon yöntemleri kullanılarak yapılmaktadır ve bu yöntem özişlem düşüncesi üzerine kuruludur. HÖ, arazi kullanımındaki değişimlerin etkisiyle mekansal simülasyon modellerinde yaygın olarak uygulanmaktadır (Ayazlı, 20I I). HÖ, sistemlerin kaotik hareket kalıplarını meydana getirmek için bileşenlerin beraber hareket ettiği modellerdir (Packard, 1985). Mekansal yayılma ve kentsel kullanımındaki değişimlerin modellenmesinde en çok kullanılan yapı, iki boyutlu hücrelerden oluşmuştur. Sonrasında üç boyutlu HÖ yöntemleri de çıkmıştır Liu, 2009).

HÖ, 1970’li yıllarda modelleme yöntemi olarak kullanılmaya başlarken, şehircilik alanında özişlem kullanımı on yıl gecikmeli olarak 1980'li yıllarda başlar. Modellemenin önemli bir aracı olarak CBS uygulamalarındaki raster analiz teknikleri ile birlikte sayısal arazi kullanım haritaları, uydu fotoğrafları HÖ için altyapı oluşturur. Hatta bazı CBS yazılımları içerisinde yer alan hazır hücresel işlem modülleri sayesinde, kentsel arazi kullanım değişimi veya ileriye yönelik kestirimlerin ve kentsel simülasyonların yapılması daha kolay hale gelmiştir. Bu alanda öne çıkan araştırmalar konularına göre şöyle sıralanabilir; kar- maşıklık ve Coğrafya Bilgi Sistemleri teorisi üzerine; Batty ve Xie (1994), Couclelis, (1997), Itami, (1994); Wolfram, (1984), Benenson ve Torrens (2004), Torrens ve O'Sullivan (200I), harita dinamikleri; Takeyama ve Couelelis, (1997), gelişen kentsel formu; Xie ve Batty, (1997), kentsel arazi kullanım dinamikleri; White ve Engelen, (1993, 1997), kentleşme biçiminin tahmini; Clarke ve Gaydos, (1998), bölgesel ölçekte kentleşme; Li ve Yeh, (2002), Hutchinson, ve Batty (1986). HÖ model yapısı özgün (heuristik) şekilde de modelleyenin kurgusuna göre değişebilir. Ancak, ne tür bir model kurgusu olursa olsun gerçekliği temsiliyet gücü test edilmelidir, ki bu modelin temsil gücü ile ilgili ayrı bir konudur.

Görüldüğü üzere, hemen tüm HÖ tabanlı modeller kent gelişiminin ve/ya arazi kullanış yer seçim ve dağılımlarının simülasyonları üzerine olmuştur. Halbuki, kentsel rant değerlemesi, tahminlenmesi ve dağılım örüntüleri üzerine ve ayrıca önemli mega projelerin sosyo-ekonomik, çevresel etkileri üzerine ve rant etkileşimin kentin yerleşim yapısına, arazi kullanım örüntülerine etkileşimi üzerine yeterli çalışma olmadığı görülmektedir. Diğer yandan, rant dağılımlarının farklı etkenler bazında (örn; mega ulaşım projeleri gibi sıçrama etki yaratabilecek), ve hücrelerin zaman etkileşimli ve etkilerinin çok katmanlı parametrelere bağı değişimi fazlaca incelenmemiştir. Orta ve uzun vadede geleceğin değerlerinin tahminlenmesinde, sıçrama etkisi yaratabilecek önemli proje ve yatırımlar, kestirimi (önceden araya böylesi bir projenin girebileceğinin öngörülmemesi nedeniyle) güçleştirmektedir. Artık, günümüz dünyasında sadece mevcut eğilimelere göre tahminleme yapılamayacağı, araya pek çok olay, teknolojik yenilik girebileceği ve dengeleri altüst edebileceği bilinmektedir. Öyleyse, yeni tahminleme simülasyon modelleri, araya ne tür proje ve yatırımların girebileceği ve olası etkilerinin neler olabileceği biçiminde senaryobazlı yaklaşım yapısıyla mutlaka değerlendirilmelidir.

\section{İzmir Körfez Tüp Geçiş Projesi ve İnciraltı Çalışma Alanı}

İzmir Körfez Tüp Geçiş Projesi, İzmir'de planlanan en önemli fakat en tartışmalı ulaşım yatırımlarından biridir. Trafik süresinin kuzey-güney bağlantısı açısından en aza indirilmesi, özellikle kent merkezinde yoğunlaşan trafik sıkışıklığının önlenmesi, yakıt maliyetinin ve hava kirliliğinin azaltılması, vapur ve feribot gibi alternatif ulaşımın sağlanması, arazi kullanımının çeşitlendirilmesi ve bütünleştirilmesi açışından önem arzetmektedir. Önerilen proje, kuzeyde Çiğli/Sasalı kavşağından başlayarak köprü ile körfez ortasına kadar devam eden ve bir ada ile birleşerek sonrasını bir tünel ile devam eden ve İnciraltı Bölgesi'nden İzmir Çeşme Otoyolu'na bağlanacak olan bir tür köprü projesidir. Proje kapsamında $12 \mathrm{~km}$ otoyol, $16 \mathrm{~km}$ raylı sistem öngörülmekte, bunlarla birlikte kuzeyde $4.2 \mathrm{~km}$ uzunluğunda köprü, $800 \mathrm{~m}$. bir yapay ada ve $1.8 \mathrm{~km}$ tüp tünel olarak öngörülmektedir (Şekil I). Tünel kesitleri; karayolu 2×3 


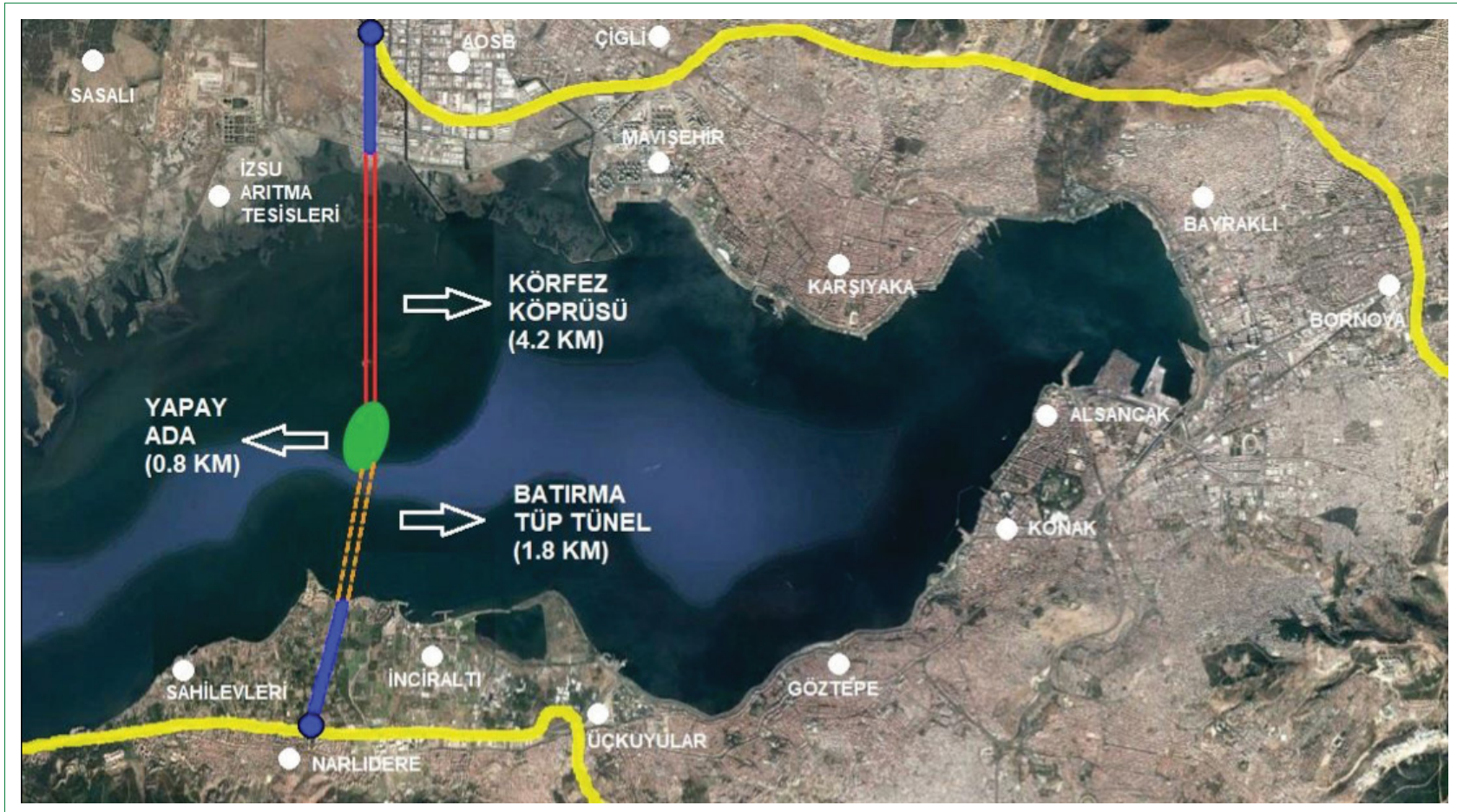

Şekil I. İzmir Körfez Tüp Geçiş Projesi - genel vaziyet planı (TMMMB, 20I5).

izli olup, raylı sistem 2xl izli olarak yaklaşık $43.40 \mathrm{~m}$. genişlikte ve $32 \mathrm{~m}$. derinlikte $9.90 \mathrm{~m}$. yüksekliğindedir (TMMMB, 20I5).

Seçilen çalışma alanı İnciraltı Bölgesi; Balçova ve Narlıdere İlçelerinde yer almakta olup; İzmir-Çeşme otoyolonun kuzeyinde, İzmir Körfezi'nin güneyinde yer almaktadır. Yönetim açısından Balçova Belediyesi'ne bağlı, İnciraltı ve Bahçelerarası Mahalleleri olmak üzere iki mahalleden oluşmaktadır. Yaklaşık 700 hektar bir ovalık alan içeren alanın toplam büyüklüğü I 200 hektar civarındadır (İzmir Büyükşehir Belediyesi, 20|4). İnciraltı Bölgesi, I., 2. ve 3. derece sit alanlarının içinde bulunduğu ve kent ormanına sahip olduğu bir alandır (Şekil 2). $\mathrm{Bu}$ alan sera ve dikili tarım üretiminin yapıldığı kentin önemli rekreasyonel mekanlarındandır. Şehir merkezinin körfez kıyı kesiminde yapılaşmanın en az olduğu İnciraltı bölgesi planlama açışından uzun yıllar İzmir'in en tartışma alanıdır. Önemli planlama kararlarından biri de İnciraltı Bölgesi Nazım İmar Planıdır. Alan turizm ve kentsel kalkınma projeleri açısından önemli bir planlama konusu olmuştur. Bölgede önemli etkilere yol açabilecek bir proje olan İzmir Körfez Tüp Geçiş Projesi de bu karar içinde yer almaktadır. Yapılan araştırmalar projenin hem İnciraltı Bölgesi'nde kentsel rant artışlarına hem de ekolojik yapının bozulmasına yol açacağı düşünülmektedir (Egercioğlu, 20।5). Bu çalışmada, şimdiye kadar düşünülen üç ayrı planlama çalışmasına göre farklı yaklaşımların izdüşümünün etkilerinin ele alınabileceği üç ayrı senaryo üzerinden, kentsel rant (gayrimenkul değer) artış (veya azalış) tahminlemesi her senaryo özelinde farklı HÖ hesaplama rutinleri üzerinden ele alınmıştır. Senaryolar, (a) mevcut yürürlükteki plan (trend), (b) koruma amaçlı "EXPO planı" (yapılaşmaya ve ranta açan) ve (c) nazım imar planını baz alan durumlardır.

\section{Materyal ve Yöntem}

Çalışma, temelde kentsel rant kavramının incelenmesi, emlak değerlerine etki eden faktörlerin belirlenmesi, CBS tabanlı HÖ yönteminin kullanımına dair genel ilkelerin tespiti ve İzmir Körfez Tüp Geçiş Projesi'nin bilgisi ile başlamıştır. Veri olarak, Balçova ve Narlıdere Belediyeleri'nden 2006, 20 I I ve 2016 yılı vergiye esas rayiç bedel değerleri elde edilmiştir. Veriler toplandıktan sonra, ArcGIS 10.3'te HÖ hücreleri bazında sayısallaştırılmıştır. Bundan sonra, arazi kullanımı kararları da İnciraltı Bölgesi'nin mevcut arazi kullanımı, Nazım İmar Planı arazi kullanım kararları ve EXPO Planı arazi kullanım kararları temelinde sayısallaştırılarak kodlanmıştır.

Diğer yandan, İnciraltı Bölgesi'nin emlak değerlerine etkide bulunan temel faktörlere odaklanılmıştır. Bunlar mevcut eğilim, İzmir Körfez Tüp Geçiş Projesi etkisi, ulaşım ve arazi kullanım faktörleri, komşu hücre etkisi (ve bununla ilgili geçiş kuralları), koruma kararı ve açıklık faktörleri olarak belirtilmiştir. Ortaya konulan formül, aralarındaki gravimetrik analizi belirlemek için faktörler için katsayılar gerektirir. Anketle elde edilen bilgiler doğrultusunda Balçova ve Narlıdere İlçeleri'nde yer alan emlak danışmanları tercih edilmek üzere I ile 7 arasında değişen Likert ölçeğine göre ağırlık katsayısı ve olası etki değerleri oluşmuştur. Sonuçlar histogramlarda incelenmekte ve faktörlerin katsayıları Likert Ölçeği diyag- 


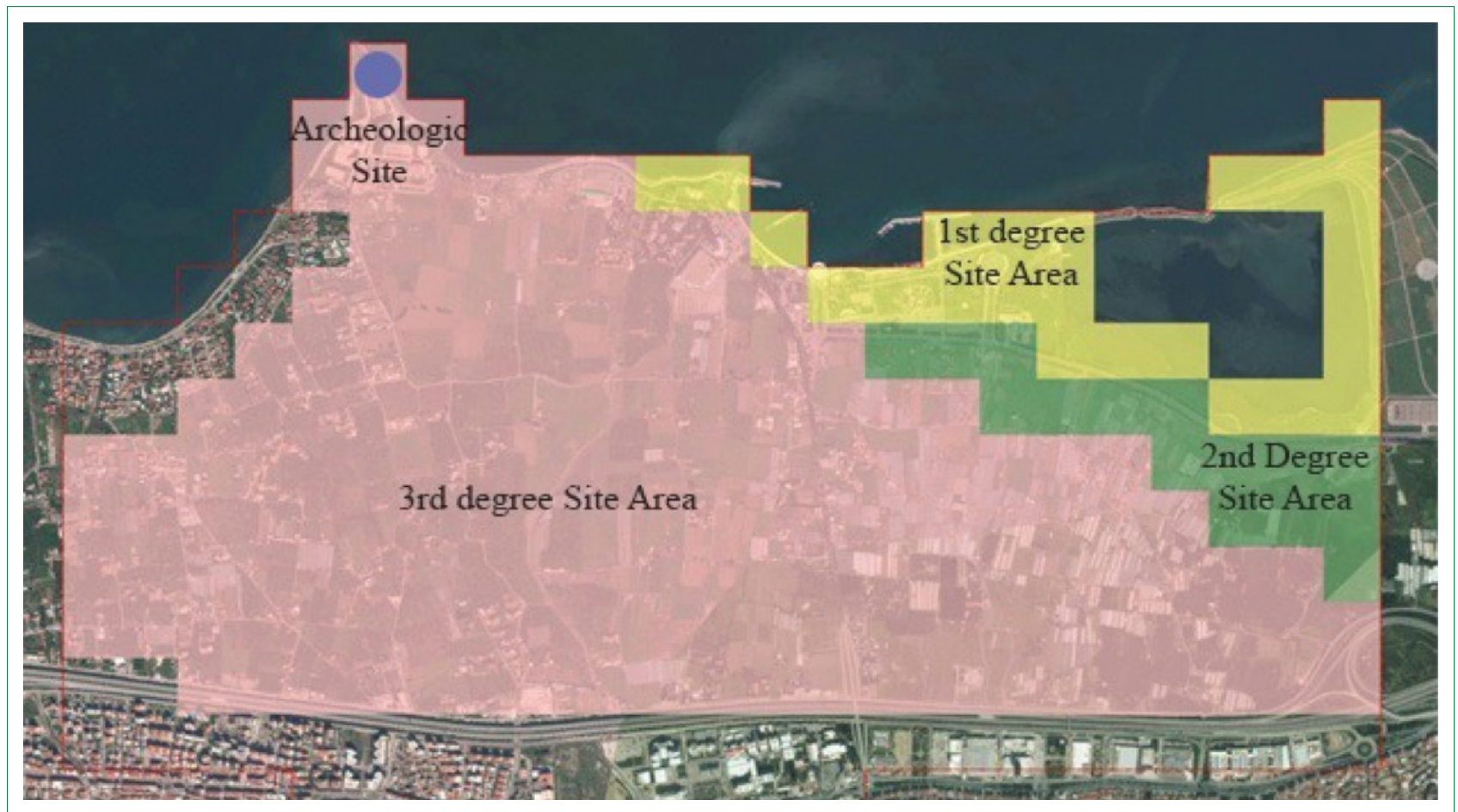

Şekil 2. İnciraltı bölgesi koruma alanları ve grid sistemine göre çalışma alanı.

ramının yüzde seviyesine çevrilmesi ile hesaplanmaktadır. Ancak, çalışmanın dar kapsamında modelleme çabasına gidilmemiş ve parametrik kalibrasyon değerlerinin eldesine girişilmemiştir.

Temelde çalışma rantsal değer artışlarının hem mevcut durum için hem de bilhassa gelecekteki $t+1, t+2, t+3, \ldots, t+n$ zamanları için olabilecek değerlenmelerin belirlenen parametrelere (faktörlere) ve katsayılara bağlı olarak en makul biçimde tahmin edilebilmesine hizmet etmek üzere kurgulanmıştır. $\mathrm{Bu}$ anlamda, tahminlemede en uygun zaman-mekansal değişim (simülasyon) yönteminin özellikle kentin (veya kentin bir bölgesinin) zaman ve mekan boyutlarına hitap edecek şekilde tespiti, ki bunun için en gelişmiş HÖ yaklaşımının literatürde kullanılan tekniklerin değerlendirilmesi sonucunda yeniden kurgulanarak, özgün bir tahmin yönteminin ortaya çıkarılması gereklidir ve en iyi temsil gücü olabilecek parametrelerin tespit edilmesi önemlidir.

Emlak değerleme tekniklerinden de faydalanarak, mevcutta bir mülk değerinin tespitinde kullanan yöntem ve teknikleri de kullanmayı amaçlayan proje yöntem önerisi ile gerçekte sadece mevcut durum (emlak) değerlemenin ötesinde gelecek zaman dilimlerinde de (ve senaryo-bazlı parametreler bazında) bu değerlerin ne olacağının tespiti en önemli getirilerdendir. Ancak rant olgusunun en önemli boyutu olan spekülatif değerlenme, komplike bir psikolojik süreç içermesi nedeniyle kapsam dışı bırakılmıştır (Duvarcı, 20।8).
Çalışmanın, rantın modellenmesi dışında diğer temel işlevi ise, yüksek rantların bir anda beklenti ötesinde "sıçrama etkisi” biçiminde oluşmasına neden olabilecek önemli ulaşım projeleri gibi mega projelerin etkilerinin de model kapsamında içselleştirilmesidir. Zira, mega proje ve yatırımlarla gelen "sıçrama” etkiler, bir anda ortaya çıkmaları ve genelde plan dışı (özellikle devlet projeleri veya başka nedenlerden "araya girerek") sürpriz gelişmeler olmaları nedeniyle, değerlerin normal seyrinin dışında dışsal bir etki olarak bilinen (normal trende göre tahminlenen) ortama müdahil olmaktadırlar. Bu nedenle normalde, orta ve uzun vadeli tahminlerde, araya girmeleri, tahminlerin zorlaşmasına ve rant değerlenmelerinde dengesizliklere, tahminde de belirsizliğe yol açarlar ve bu kaotik etkiler tüm kent çapında dahi hissedilebilir. Bu anlamda daha mekanik ve sabit yer bazlı emlak değerleme sürecine kıyasla daha karmaşık ve spekülatif rant değerleme arasında kıyaslanabilir bir fark oluşur. Çalışmamızın model kurgusu içerisinde, yine, İzmir Körfez Tüp Geçiş Projesi gibi henüz uygulanmamış ama uygulanması yakın zamanda düşünülen önemli bir projenin özellikle bu tür araya giren mega proje etkisine örnek olarak, düşünülmesi ve kentsel rantlara ne tür bir sıçrama etkisi yapabileceğini yine CBS tabanlı HÖ düzeneğinde irdelemek yeni ve önemli yaklaşımlardan biri olacaktır.

\section{Hücresel Özişlem Yöntemi}

HÖ'de her hücre belli bir "durum”a (state) sahiptir ve bu durum çevresindeki hücrelerden etkilenmektedir. Kentsel tabanlı HÖ modellerinde, hücrenin durumu arazi kullanım türü veya kentsel arazi olarak vasıflandırılabilir. 


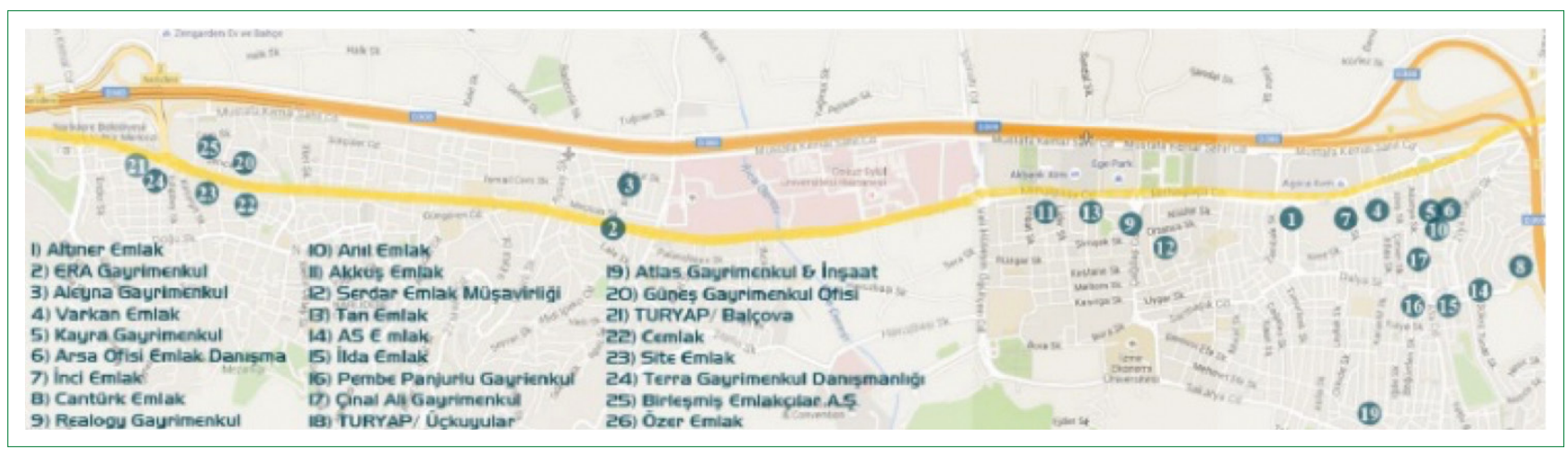

Şekil 3. Anket uygulanan emlak danışmanlarının lokasyonları.

Komşuluk, hücrenin etkileşimde bulunduğu diğer hücrelerden oluşan kümeyi ifade eder. Von Neumann'ın çalışmasında (1966), kuzey, güney, doğu ve batı yönlü komşuluklar kullanılırken; Moore'un çalışmasında ise, kuzeydoğu, kuzeybatı, güneydoğu ve güneybatı yönlerindeki komşuluklar da kullanılmıştır (Moore, 1964).

Geçiş kuralları, hücrenin mevcut durumuna ve komşularının durumlarına nasıl yanıt vereceğini gösterir. Bu kurallar, sistem modelleme sürecini temsil ettikleri HÖ'in anahtar bileşenidir (White vd., 1997). HÖ geçiş kuralları benzer olup, tüm hücrelere eş zamanlı uygulanmaktadır. Bu nedenle zaman faktörü en önemli parametrelerden biridir. Yalnız bu esnek bir kuraldır ve kullanıcı tarafından diğer hücreler için başka zamanlar da sınırlandırılabilmektedir. Kurallar özişlemin zamanı ile uygun bir şekilde çalışır, gelen bilgi neticesinde durumunu doğrulayacak olan özişlemin belirli bir zaman aralığına bağlıdır (Hutchinson ve Batty, 1986). Kendi çalışmamızda, parametre ağılıklarını belirlemek amaçlı, çeşitli katmanlara göre yapılan anketler emlak danışmanlarının verdiği cevaplar sonucu likert değer olarak toplanan veriler, yüzde katsayı değerlerine dönüştürülerek değişkenlerin ağırlıkları faktör çarpanları olarak kullanılmıştır.

Kullanılan temel parametreler; arazi kullanımı ve yoğunluğu, arazi kullanımlarının kentsel ranta getirisinin önemi, çevresinin açık ve ferah olmasının etkisi, sit alanlarının emlak değer artışlarına etkisi, kentin alt merkezlerine uzaklıklığın (Konak, Karşıyaka, Bornova vb.), erişebilirliğin (toplu taşıma durakları vb.), bağlantı yollarının, anayola yakınlığın ne derece etkili olduğu, yapımı planlanan köprü projesinin genel olarak emlak değerlerine olası etkisi, belirli bir mesafedeki (400 m.) yerlerin birbirlerine etki oranı, donatı ve kentsel kullanımların (AVM, otopark, hastane, park vb.) yakın mesafedeki (400 m.) yerlerin emlak değerine etkisi olmak üzere, sekiz sorudan oluşan 7'li likert tekniğinin kullanıldığı bir anket çalışması ile belirlenmiştir.

Bölgedeki emlak danışmanlarıyla (Şekil 3) yapılan anketler sonucunda hücresel etkilerin hesaplamaları yapıldığında, formüllerdeki kategorik faktörlerin ortalama (tüm emlakçıların cevap değerleri ortalaması) değer yüzdeleri faktör değeri olarak kullanılmıştır.

Arazi kullanımı ve yoğunluğu toplamı; ticari faaliyet, yerleşim alanı, kamu ve çalışma alanı ve kırsal alan toplamı; kentsel alanlara uzaklık, bağlantısallık (connectivity) kentlere olan uzaklık ve toplu taşımaya olan uzaklık gibi kendi içindeki kategorilerle toplamda \% I00 olarak tamamlanmıştır (Şekil 4). Anketlerden elde edilen veriler kullanılmadan önce, istatistiki tutarlıklıkları açısından histogram dağılımlarına bakılmış ve ayrıca varyans, standart sapma değerlerine de bakılarak verilerin normal dağıIım sergileyip sergilemedikleri incelenmiştir. Anketlerden elde edilmiş olan söz konusu katsayı çarpanları her faktörün ne derece etkili olduğu hususunda bilgi sağlanmıştır.

Literatürde, erişilebilirlik, arazi kullanım yoğunluğu vb. emlak değerlerini etkileyen rant parametreleri incelenmiş olup, bunlar baz alınarak yeni bir yorumla hesaplamaya gidilmiştir. Yoğunluk ve büyük ölçekli kentsel kalkınma projeleri ile olan etkiyi incelemek için komşuluk etkisini de eklemek gerekir (Gonzále, 20I5). Bunun yanında kentsel merkezlere uzaklık, kentsel olanaklara olan uzaklık ve arazi kullanımı da önemlidir (Blecic vd., 20I2). Bunların yanı sıra, komşuluk etkisi çoğunlukla HÖ yöntemi ile ilişkili olan hücre etkisine dayanmaktadır (White ve Engelen, 1993; White vd., 1997).

Belirlenen çalışma alanlarında CBS tabanlı HÖ ızgara (258 hücre) düzeneği kurularak, farklı senaryolar bazında (bir senaryo İzmir Körfez Tüp Geçiş Projesi'nin uygulanacağı kabulüne göre, bölgeye rant etkilerinin olacağı, bir senaryo projenin uygulanmayacağı ve mevcut eğilimlerin devam edeceği kabulü, ve diğer senaryoda da farklı bir nazım imar uygulamasının olacağı kabül ve daha fazla senaryo gerektiğinde eklenebilecektir), her bir "senaryoya özgü" farklı parametre ve katsayıların belirleneceği bir yöntem yaklaşımı çalışılmıştır (örneğin, bir senaryoda körfez tüp geçişi var diğerinde ise yok).

Geçmişteki eğilim bilgisinin de değerlendirileceği biçimde t0 mevcut zamanın (20l6) gerisinden de t-I (20l I), t-2 (2006), ... t-n "koşullandırma” eğilim belirleme parametresi elde edilir. 


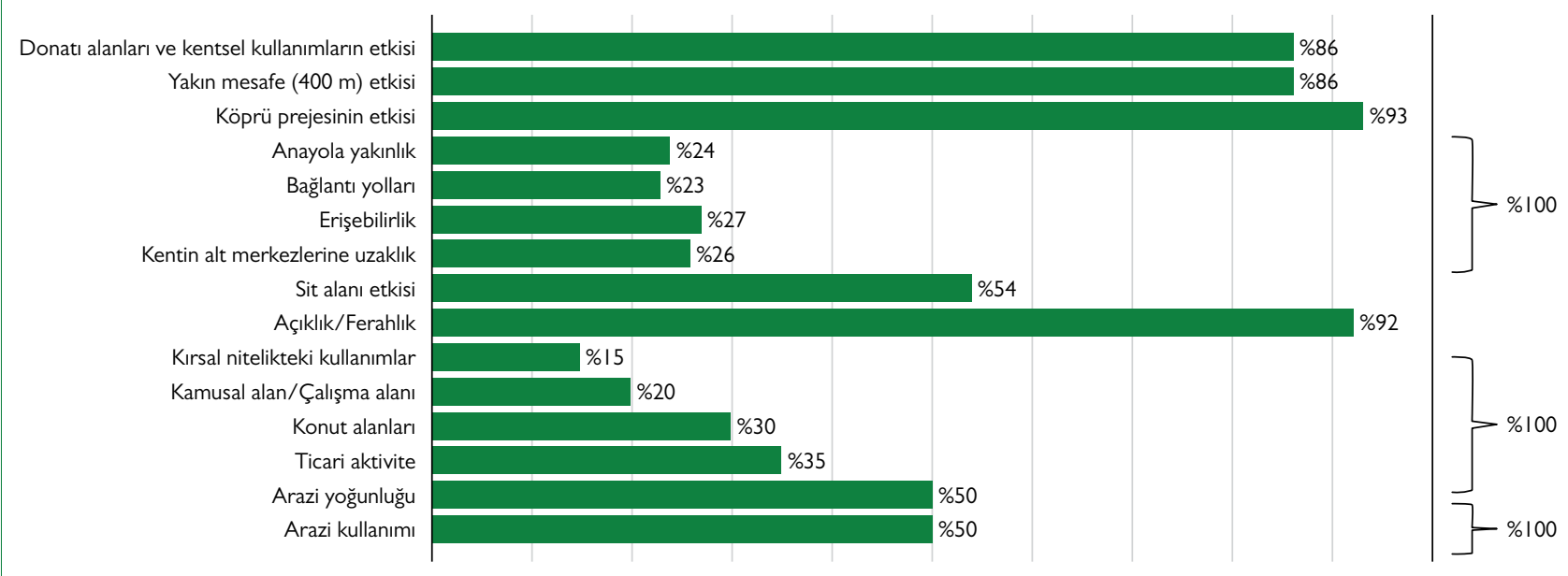

Şekil 4. Anket sonuçları ve simülasyonlarda kullanılacak katsayı değerleri.

$t_{0}$ zamanın değerleri mevcudun değeri olup halihazırda bilinen rant değerleridir (mevcut emlak değerleri, rayiç bedel, vergiye esas kamulaştırma bedelleri vb.) sonrasında da $t+l$ (202l), $\mathrm{t}+2$ (2026), $\mathrm{t}+3$ (203I), ... t+n zamanlarında rant değerlerinin tahminlenmesi için söz konusu eğilim parametresiyle birlikte ek olarak geleceğin tahminlemesine etki edecek diğer faktörler birer girdi olarak formüle eklenir. Tüm hesaplamalar temelde hücre-bazlı devam eder, ancak gerektiğinde bölgecik bazında (zonal) diyebileceğimiz daha toplu (benzer karakteristikleri haiz hücre grupları bazında, örn; ticaret, kamu, donatı alanları vb.) hesaplama da söz konusudur (Şekil 5).

Buna göre temelde lineer yapıdaki gelecek rantı:

$$
R_{t+n}=R_{0} \cdot f\left(F_{x}\right)+T_{x}
$$

$R_{t+n}$ : tahminlenmesi istenen gelecekteki $n$ sonrası dönemin rant değeri (hücre bazında $\mathrm{m}^{2}$ başına)

$R_{0}$ : mevcuttaki rant değeri (emlak rayiç değeri)

$f\left(F_{x}\right)$ : belli bir $x$ sayıda faktörün (parametre) içerildiği faktörlerin fonksiyonu (F, O'dan ve I'den büyük olabilir)

$T_{x}$ : belli bir $x$ sayıda değere doğrudan eklenen diğer etmenler ek değerleri

\section{Ele Alınacak Temel Parametreler}

$F\left(F_{x}\right)$ parametreleri (fonksiyona her parametre için $0<F>1$ arasında faktör çarpanı olarak tespit edilip girilen değerdir, sonuçta I'den az olursa rant değerini azaltan, I'den çok olduğunda rant değerini artıran bir çarpan) her biri ayrı ayr hesaplanır (Şekil 6) ve hesaplamada alt-parametreler vardır:

a) Ulaşım faktörü:

tr: ulaşım faktörü

$$
f(t r)=k f(c)+I\left(d_{m c}\right)+m\left(d_{d}\right)
$$

c: bağlantı (connectivity index) faktörü

$d_{m c}$ : ana merkezlere olan uzaklık ( $\mathrm{dk}$ )

$d_{a}$ : kentsel olanaklara olan uzaklık b) Bağlantısallık (connectivity) alt faktörü:

$$
f(c)=\frac{\frac{\sum x^{i} t+1}{n^{i} t+1}-\frac{\sum x^{i} t}{n^{i} t}}{\frac{\sum x^{i} t}{n^{i} t}}+1
$$

$x$ : yolların toplam uzunluğu

$n$ : bölgedeki hücre sayısı

t: zaman

t+ I: I/I 000 ölçekli İnciraltı Bölgesi Koruma Amaçlı İmar Planı (EXPO)

c) Şehrin ana merkezlerine olan uzaklık alt faktörü:

$$
f\left(d_{m c}\right)=\frac{\sum d_{m c^{i}} t-\sum d_{m c^{i}} t+1}{\sum d_{m c^{i}} t}+1 \text { (zaman cinsinden) }
$$

$d_{m c}$ : ana merkezlere olan uzaklık ( $\left.\mathrm{dk}\right)$

$t:$ zaman

t+ I: I/ 1000 ölçekli İnciraltı Bölgesi Koruma Amaçlı İmar Planı (EXPO)

d) Diğer kentsel kullanımlara olan uzaklık alt faktörü:

$$
f\left(d_{a}\right)=\frac{\sum d_{a^{i}} t-\sum d_{a^{i}} t+1}{\sum d_{a^{i}} t}+1\left(\mathrm{~m}^{2} \text { cinsinden }\right)
$$

$d_{a}$ : kentsel kullanımlara olan uzaklık

$t:$ zaman

t+ I: I/I000 ölçekli İnciraltı Bölgesi Koruma Amaçlı İmar Planı (EXPO Plan)

e) Arazi Kullanım Faktörü:

$$
\begin{aligned}
& f(l u)=I+(I . l j) \\
& l j=f(t+I)-f(t)
\end{aligned}
$$

$f(l u)$ : arazi kullanım faktörü değeri

lj: arazi kullanım katsayılarının $\mathrm{t}+\mathbf{I}$ zamanındaki değişimi

$f(t)$ : t zamandaki arazi kullanım tiplerinin katsayısı (ticaret, konut alanı, kamusal, vb.) 


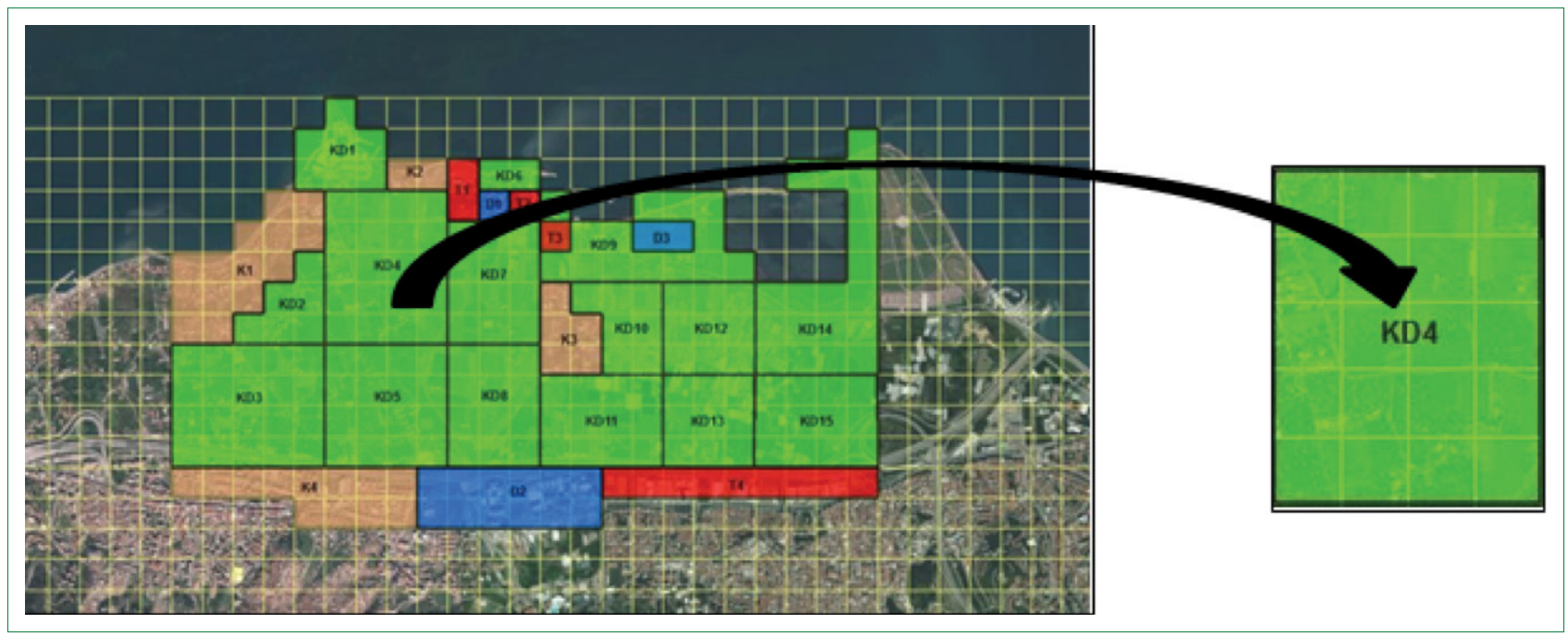

Şekil 5. Örnek HÖ planı ve zonal hücrelerin gösterimi.

f) Koruma alanı etkisi:

$$
f(c)=\frac{x \cdot s}{n-s}
$$

$x$ : sit alanının belirlenen katsayısı

$n$ : bölgedeki hücre sayısı

s: sit alanı hücre sayısı

g) İzmir köprü tünel geçiş projesinin etkisi:

$$
K T G=\sum\left(R^{i} t . g\right)
$$

KTG: köprü tünel geçişi etkisi

g: tüp geçiş projesinin genel etkisi (\% olarak)

$R$ : sit koruma alanı ve/veya kamu kullanımının olduğu etkilenmemiş hücreler

h) Komşu hücre etkisi:

$$
\begin{gathered}
E_{t+1 K H}^{i}=E_{t+1}^{i}+T_{K H}{ }^{i} \\
T_{K H}{ }^{i}=\sum\left[R^{h(i)}{ }_{t+1} \times\left(h / n_{h}{ }^{i(n s k k)}\right)\right]
\end{gathered}
$$

$n_{h}^{i(n s k k)}$ sitleri çevreleyen ve/veya kamu alanı olmayan hücrelerin sayısı

$R^{h(i)}$ : ele aldığımız komşu hücrelerinin emlak rayiç değeri

$T_{K H}$ : komşu hücrelerin etkilerinin toplamı

$E_{t+1 ~ K H}^{i}:$ komşu hücrelerin etkisinden aldığı değerler toplamı

\section{Tx Eklenti değer parametreleri:}

- Hücresel etkileşim, HÖ'nin kendi doğal "işlem” parametresidir. Burada özgün kabullere göre hesaplanan değerler hücrede $f\left(F_{x}\right)$ olarak bulunan değerlere doğrudan ekleme yapılan "ekleme" değeridir.

- Kamusal alan, veya sit koruma alanı kararlarının olup olmaması,

- Baz eğilim (trend) etkisi de eğim değeri oranında (örn; her yıl ortalama min. \%10 mutlak artış varsa) genelde doğru- dan eşit oranlarda her hücreye eklenir (tüm bölgeye eşit düzeyde yansıması gereken parametre olarak)

- Sıçrama etkisi yaratabilecek mega proje etkisi de görüldüğü dönem, bu etkinin kabul edildiği senaryolarda $f\left(F_{x}\right)$ değerine eklenir.

Sonuçta tüm bu faktörler ve bahsi geçen etkiler temelde aynı anda birbirinden bağımsızmışçasına hücrede $t(x)$ zamanı için işleme alınırken, diğer yandan, aynı anda ve sonraki anları etkileyecek biçimde komşuluk kuralları işleme alınacaktır.

Coğrafi temsil, küme hücreleriyle yapılmıştır. Arazi kullanımları ve korunan alanlar, kümelenmiş-hücreler olarak temsil edilmiştir (örn; $\mathrm{KI}$ : konut alanı bölgesi zonu, DI: donatı bölgesi zonu) Daha sonra, imar sistemine aktarılırlar (Şekil 7). Düzenli ızgara sistemi; standart ızgara yapısını, hücresel alanı homojenleştiren, süreci analiz eden verileri basitleştiren, arazi kullanımı ve haritalama için kümelenmiş (zonlu) bir yapıya sahip olup, sokaklardaki değer değişikliklerini kiralamak için 200 m mesafeye (4 ha) koordine edilmektedir.

Yöntemin basit ve temel kuralı, her bir parametre etken değerinin ayrı ayrı hesaplanması ve her hücre için toplam değerin bulunmasıdır. Rant ile ilgili tespitler yapabilmek, bölgedeki emlak değerlerindeki değişimi görebilmek ve geleceğe dair yorumlar yapabilmek, olguyu ve ilgili sistemleri açıklayıcı model geliştirmek, parametreleri belirlemek ve bu parametrelerin her senaryo bazında değiştirerek rant tahmin sonuçlarını belirleyebilmek burada temel hedeftir.

\section{HÖ Simülasyon Sonuçlarının Değerlendirilmesi}

Çalışmada faktörlerin etkilerini ölçmek için hazırlık sürecinin tamamlanmasından sonra, $\mathrm{t}+\mathrm{l}, \mathrm{t}+2$ ve $\mathrm{t}+3$ dönemlerini 


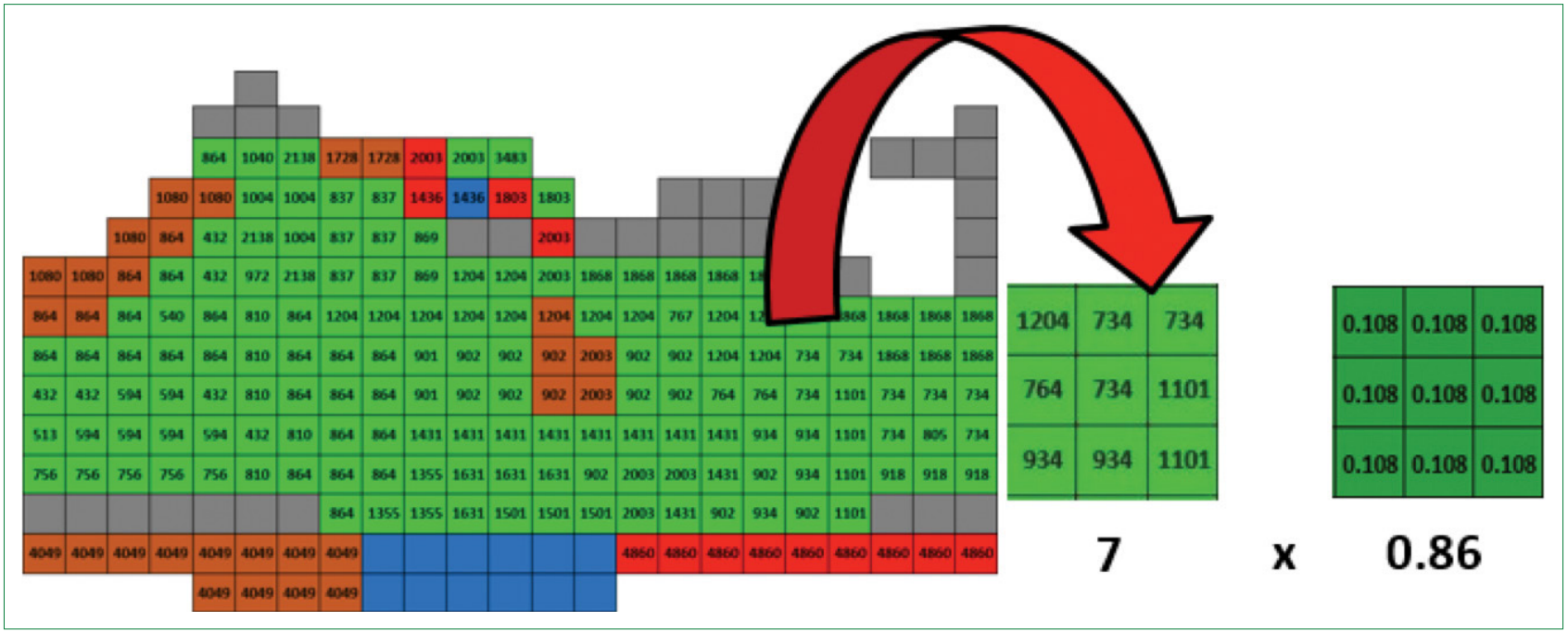

Şekil 6. Örnek HÖ planı üzerinde hesaplanan emlak rayiç değerleri (TL cinsinden)

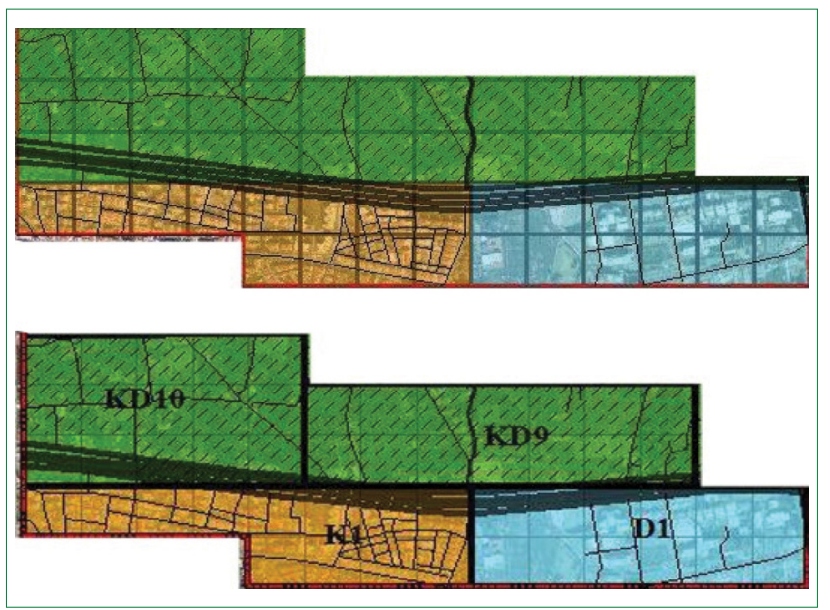

Şekil 7. Arazi kullanımıın kümelenmiş hücreler ile gösterimi.

ölçmede mevcut plan, Nazım plan ve EXPO Planı için ayrı hesap şemaları uygulanmıştır. Daha sonra, tahminlenen değerler sınıflandırılır ve her bir sonuç, tanımlayıcı istatistiklere göre değerlendirilmiştir. Bütün ölçüm ve karşılaştırmalar tamamlandıktan sonra, kentsel rantın göz ardı edilmesi, rantta direnme ve ranttan yararlanma gibi farklı açılardan üç çeşit planlama yaklaşımı senaryoları üretilmiştir (Şekil 8). Faktörlerin, etkilerini belirleyebilmek için formülasyonda farklı zamanlarda eklemeler yapılmıştır. Bu kapsamda, trend faktörü, körfez geçiş projesi, ulaşım ve arazi kullanım faktörleri $\mathrm{t}+\mathrm{I}$ tarihinde eklenmiştir. Ayrıca, trend faktörü, koruma alanı faktörü ve komşu hücre etkileri $t+2$ 'ye dahil edilirken; eğilim ve komşu hücre etkisi $\mathrm{t}+3$ zamanında dahil edilmiştir.

Eğilim artışı, mevcut planlama durumunda ( $I$. senaryo), çalışmada doğrusal olarak kabul edilirken, belediye vergi değerindeki ortalama artış 2006 (emlak değeri ortalaması
323.62 TL) yılından 20II (emlak değeri ortalaması 767.8I TL) yılına kadar \%250'dir; 201 I yılından 2016 (emlak değeri ortalaması III9.6I TL) yılına kadar \%/20'dir. Bu nedenle, bu araştırma için genel trend eğilimi beş yılda ortalama $\% 60$ olarak varsayılmıştır. Bu trende göre $\mathrm{t}+\mathrm{I}$ (202I) zamanında tahmini ortalama emlak değeri 1791.37 TL olurken, $\mathrm{t}+2$ (2026) için zaman içinde 2328,78 TL, t+3 (203I) için 2678, I TL olacaktır.

Nazım İmar Planı'nı (2. senaryo) ele aldığımızda, projenin olmadığı varsayımına göre belirli faktörleri hesaba katarak yaptığımı simülasyon senaryosunda, proje gerçekleşmese bile CBS tabanlı HÖ ile yapılan simülasyonlarda, yıllara göre arazi değeri, konum, eğilim, komşu hücre etkisi baz alındığında emlak rayiç değerlerinin arttığı gözlemlenmiştir. Bu artış, K. Marx'ın da değindiği emek dışındaki artı değerden gelmektedir (Marx, 1998). Nazım İmar Planı simülasyon senaryosunda, diğer iki plana göre kentsel rantta büyük farklılıkların olmadığı gözlemlenmiştir. Yani neredeyse eşit dağıımın yapıldığını ve eşitsizliğe neden olmayacağı söylenebilir.

Son olarak EXPO Planı ile (3. senaryo), diğer iki simülasyondan farklı olarak daha fazla konut ve ticaret alanına sahip bir arazi kullanım düzeniyle birlikte $\mathrm{t}+\mid$ zamanda ortalama emlak değeri 8.159 TL, $t+2$ zamanda ortalama emlak değeri 18.659 TL ve $t+3$ zamanda ise ortalama emlak değeri 33.912 TL gibi ciddi bir emlak artış değeri olup, mevcut plana kıyasla bu oran yaklaşık 20 kat fazladır. Bu oran her yerde eşit bir dağıım göstermemektedir. Örneğin $t+3$ zamanı olarak nitelendirdiğimiz 2031 yılı simülasyonunda minimum emlak rayiç değeri 5.518 TL iken maksimum emlak rayiç değeri 192.168 TL olarak hesaplanmıştır. Bu da İnciraltı Bölgesi'ni ciddi rant sorunlarıyla karşı karşıya bırakmaktadır. Rant sorununa yol açan faktörlerin hangilerinin öne çıktığı konusu ayrı bir çalışmada ele alınarak değerlendirilecektir. 


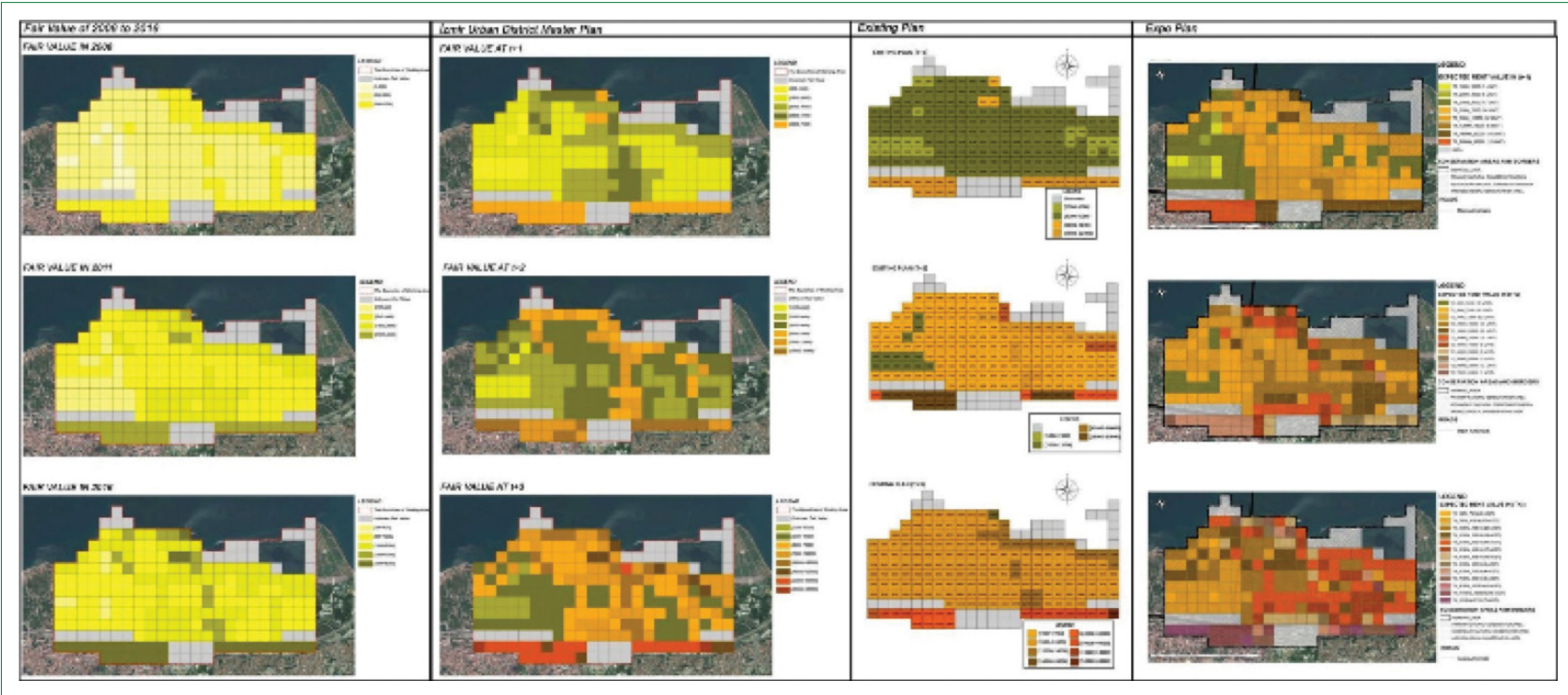

Şekil 8. Üç farklı planlama senaryonun karşılaştırılması.

\section{Sonuç}

Bu çalışma kapsamında henüz gerçekleşmemiş fakat gerçekleşme intimali yüksek olan büyük ulaşım projelerinin (burada İzmir Tüp Geçiş Projesi) kentsel rantlara ne derece etkide bulunup bulunamayacağı irdelenmiş, dolayısıyla kent yapısına olabilecek değişikliklerin, değişen rantlar üzerinden okunabilirliği sağlanmıştır. Söz konusu olası değişim, tüm çalışma alanı küçük hücrelere bölünmek suretiyle ayrıca bu hücrelerin kendi aralarındaki etkileşiminin de zaman içinde ele alındığı biçimde özgün HÖ şeması bazında CBS kullanılarak gözlenmiştir. Bu şekilde, aynı zamanda, HÖ tahminleme süreci hem kesikli zaman boyutunda gözlenebilmiş hem de CBS uygulamasına entegre edilebilmiş (ki, plancıların kolayca ele alabileceği şekilde) ve senaryo bazında değerlendirmeler elde edilebilmiştir.

Bugüne değin gerek rant baskılarını önleyici gerekse rant-bazlı planlama yaklaşımlarıyla İnciraltı Bölgesi gibi hassas alanlar ilgi odağı konumuna gelmiştir. İzmir'in batı aksında yer alan Inciraltı-Sahilevleri bölgesi artık mevcut haliyle ve bunun yanında rant baskılarından uzak tutacak şekilde korumak pek mümkün görünmemektedir. Tartışmalı bölgenin örnek çalışma alanı olarak ele alındığı çalışmamızda, çeşitli faktörlere dayalı olarak rant tahminlemesi CBS tabanlı HÖ yöntemi kullanılarak denenmiş ve üç farklı plan bazında üç senaryo üzerinden çıkan değerler karşılaştııılmıştır. Geleceğe ilişkin tahminleme ise bugünden başlayarak (2016) beşer yıllık üç ardışık dönem için yapılmıştır. Özellikle turizm gelişimi eksenli "EXPO Planı" senaryosunda İzmir Tüp Geçiş Projesi'nin emlak değerlerine olabilecek sıçrama etkisi de ele alınmış ve özellikle projede belirtilen tüp geçişe bağlantı yolları üzerinde rant artışları tespit edilmiştir. Her üç senaryoda da rantlar artış göstermiş ancak kimisinde aşırı düzeyde artışlar, üstlendikleri paramet- relere göre de makul düzeyde artışlar kaydedilmiştir. Burada elde edilen bulgular, temelde belirlenen yöntemin ne derece işlevsel ve planlamada ne derece kullanışlı olabileceği üzerinedir. Özellikle, yöntemin, arazi kullanım-ulaşım (EXPO, nazım imar, vb.) plan kararlarına göre rantların ileride nasıl değer alabileceğine olan yol göstericiliği, gelecekteki kentsel oluşumlara olası etkileri ve bu anlamda, planlamada bir karar-destek aracı olarak kullanılabilirliğinin olabileceği vurgulanmıştır. Yöntemin işe yararlılı̆ı üzerinde durularak, spesifik bulguların ne olduğu şimdilik bu çalışmada ele alınmamıştır. Çıkan sonuçların gerçekliği test edilmemiştir, yani önerilen modelin sınaması henüz yoktur. Böylece, söz konusu tahminlenen öneri plan ve özellikle büyük projelerin (şimdilik kesinliği söz konusu olmasa da) gelecekteki rantsal etkilerinin çevresel/sosyal etkileri irdelenebilir, ki ileride yöntem bir CBS-tabanlı bir (eklenti) yazilım uygulamasına dönüştürülebilir.

\section{Teşekkür}

Bu çalışmanın veri toplama ve işleme aşaması, İzmir Yüksek Teknoloji Enstitüsü Şehir Planlama Anabilim Dalı Yüksek Lisans Programı CP 502 - Planlama Stüdyosu öğrencileri Hilal Alıpatar, Kardelen Ekin Şahin, Gökçe Demircan, Ezgi Gül Erdem tarafından gerçekleştirilmiştir. 


\section{KAYNAKLAR}

Ayazlı, İ. (2011). Ulaşım Ağlarının Etkisiyle Kentsel Yayılmanın Simülasyon Modeli: 3. Boğaz Köprüsü Örneği. (Yayımlanmamış doktora tezi). Yıldız Teknik Üniversitesi, İstanbul.

Balchin, P., Bull, G. (1987). Regional and Urban Economics. London, UK, Harper \& Row Ltd.

Batty, M., Xie, Y. C. (1994). From Cells to Cities. Environment and Planning B, 21, 31-48.

Benenson, I., Torrens, P. M. (2004). Geosimulation: Object-based Modeling of Urban Phenomena. Computers, Environment and Urban Systems, 28, $1-8$.

Blecic, I., Cecchini, A., Trunfio, G. A. (2012). Parallel Simulation of Urban Dynamics on the GPU. International Conference on Computational Science and its Applications (ICCSA), Omaha, USA, 4-6 June.

Clark, K., Hoppen, S., Gaydos, L. (1997). A Self-Modifying Cellular Automaton Model of Historical Urbanization in the San Francisco Bay Area, Environment and Planning B, Vol. 24, 247-261.

Clarke, K., Gaydos, L. J. (1998). Loose Coupling a Cellular Automaton Model and GIS: Long-term Urban Growth Prediction for San Francisco and Washington/Baltimore. International Journal Geographical Information Science, 12, 699-714.

Couclelis, H. (1997). From Cellular Automata to Urban Models: New Principles for Model Development and Implementation. Environment and Planning B, 24, 165-174.

Duvarcı, Y. (2018). Rantın Elli Tonu. Ankara: Gece Kitaplı̆̆ı Yayınevi.

Egercioğlu, Y., Ercoșkun, Ö. (2015). İzmir'de Sürdürülebilir Kentsel Planlama İçin Expo Alanının Sunduğu Riskler ve Firsatlar. Planlama Dergisi, 15, $8-20$.

Evans A. W. (1991). On Monopoly Rent. Land Economics, 67, 1-14.

Gonzále, P. B., Gómez-Delgado, M., Benavente, F. (2015). Vector-based Cellular Automata: Exploring New Methods of Urban Growth Simulation with Cadastral Parcels and Graph Theory. CUPUM 2015, International Conference on Computer in Urban Planning and Urban Management, Cambridge, USA, 7-10 July.

Harvey, J. (1996). Urban Land Economics. London, UK, Macmillan.

Hutchinson, B., Batty, M. (1986). Advances in Urban Systems Modelling, Urban Transport Planning: A Development Approach. Dimitriou H. (Ed.). United Kingdom: Routledge.

Itami, R. (1994). Simulating Spatial Dynamics: Cellular Automata Theory. Landscape and Urban Planning, 30, 24-47.

İzmir Büyükşehir Belediyesi (2014). Balçova Turizm Merkezi İnciraltı Kesimi Raporu. İzmir.

Kalabalık, H. (2011). İmar Hukuk Dersleri (3. Baskı). Ankara: Seçkin Yayincilik.

Keleş, R. (2004). Kentleşme Politikası. Ankara: İmge Kitabevi.

Landis, J. (1995). Imaging Land Use Features: Applying the California Urban Futures Model. Journal of American Planning Association, 61, 438-457.

Li, X., Yeh, A. (1998). Modeling Sustainable Urban Development by the Integration of Constrained Cellular Automata and GIS. International Journal of Geographical Information Science, 2000, 14, 2, 131-152.

Li, X., Yeh, A. (2002). Neural-Network-based Cellular Automata for Simulating Multiple Land Use Changes Using GIS. International Journal of Geographical Information Science, 164, 323-343.

Liu, L., Wang, X., Eck, J., Liang, J. (2005). Simulating Crime Events and Crime Patterns. Editor: Wang F. Geographic Information Systems and Crime Analysis, 198-213, USA: Northern Illinois University.

Liu, Y. (2009). Modelling Urban Development with Geographical Information Systems and Cellular Automata. London, UK: CRC Press, Taylor $\&$ Francis Group.

Marx, K. (1998). Artı Değer Teorileri. Çeviri: Yurdakul Fidancı, Sol Yayınları, Ankara.
Meaille, R., Wald, L. (1990). Using Geographical Information Systems and Satellite Imagery within a Numerical Simulation of Regional Urban Growth. International Journal of Geographical Information Systems, 4, $445-456$.

Moore, E. (1964). The Firing Squad Synchronization Problem, Sequential Machines. Editor: Moore E. (Ed.), Addison-Wesley, Reading, 213-213, MA.

Packard, N., Wolfram, S. (1985). “Two-Dimensional Cellular Automata. Journal of Statistical Physics, 38, 901-946.

Sui, D., Zeng, H. (2001). Modeling the Dynamics of Landscape Structure in Asia's Emerging Desakota Regions: A Case Study in Shenzhen. Landscape and Urban Planning, 53, 37-52.

Takeyama, M., Couclelis, H. (1997). Map Dynamics: Integrating Cellular Automata and GIS through Geo-Algebra. International Journal of Geographical Information Science, 11, 73-91.

Torrens, P, O'Sullivan, D. (2001). Cellular Automata and Urban Simulation: Where Do We Go from Here? Environment and Planning B: Planning and Design, 28, 163-168.

Turner, B., Moss, R., Skole, D. (1993). Relating Land use and Global Land Cover Change: A proposal for an IGBP-HDP Core Project. International-Geosphere-Biosphere Program, IGBP Report No. 24, HDP Report No: 5, Stockholm: Royal Swedish Academy of Sciences.

Türk Müşavir Mühendisler ve Mimarlar Birliği (2015). İzmir Körfez Geçişi Sunumu, Yüksel Proje Uluslararası A.Ş. http://www.tmmmb.org. tr/images/Etkinlikler/9_TMK/ozgur_ugurlu.pdf (Erişim Tarihi: 23.08.2018).

White, R., Engelen, G (1993). Cellular Automata and Fractal Urban Form: A Cellular Modelling Aproach to the Evolution of Urban Land Use Patterns. Environment and Planning A, 25, 1175-1199.

White, R., Engelen, G., Uljee, I. (1997). The Use of Constrained Cellular Automata for High-resolution Modelling of Urban Land-use Dynamics. Environment and Planning B, 3, 323-343.

Von Neumann, J. (1966). Theory of Self-Reproducing Automata. UMl Reprint University Illinois.

Wolfram, S. (1984). Universality and Complexity in Cellular Automata. Physica D, 10, 1-35.

Xie, Y., Batty, M. (1997). Automata-based Exploration of Emergent Urban Form. Geographical Systems, 4, 83-102.

Yüzer, M., Yüzer, Ş. (2006). Cellular Automata Tabanlı LUCAM Modeli ile İstanbul'un Gelişim ve Dönüşümüne İlişkin Makro Form Simülasyonlar1. Journal of İstanbul Kültür University, 4, 231-244. 